\author{
Abstracta Iranica \\ Abstracta Iranica Revue bibliographique pour le domaine irano-aryen \\ Volume 37-38-39 | 2018 \\ Comptes rendus des publications de 2014-2016
}

\title{
Simon Worrall. The Lost Dhow. A Discovery from the Maritime Silk Route
}

\section{Iván Szántó}

\section{(2) OpenEdition \\ 1 Journals}

\section{Electronic version}

URL: http://journals.openedition.org/abstractairanica/42690

DOI: $10.4000 / a b s t r a c t a i r a n i c a .42690$

ISBN: 1961-960X

ISSN: 1961-960X

Publisher:

CNRS (UMR 7528 Mondes iraniens et indiens), Éditions de l'IFRI

Electronic reference

Iván Szántó, «Simon Worrall. The Lost Dhow. A Discovery from the Maritime Silk Route », Abstracta Iranica [Online], Volume 37-38-39 | 2018, document 7, Online since 10 March 2018, connection on 29 September 2020. URL : http://journals.openedition.org/abstractairanica/42690 ; DOI : https://doi.org/ 10.4000/abstractairanica.42690

This text was automatically generated on 29 September 2020

Tous droits réservés 
Simon Worrall. The Lost Dhow. A Discovery from the Maritime Silk Route

Iván Szántó 


\section{REFERENCES}

Simon Worrall. The Lost Dhow. A Discovery from the Maritime Silk Route, Toronto, Aga Khan Museum, 2014, 63 p. ISBN: 978-0991992898

1 What warrants mention of this publication in spite of its popular tone is, firstly, the exceptional archaeological assemblage which it makes accessible and, secondly, its documentary value as a new addition to the still scantly published material about the so-called Belitung shipwreck, an outstanding find recovered (in 1998) by a highly controversial project of recent maritime archaeology. The Belitung ship is the first and only salvaged boat surviving from the 'Abbasid Caliphate. Built at one of the ports of the Persian Gulf or Oman, it was on its way back from the East China Sea when it sank in the Gaspar Strait, off the coast of Sumatra. Its cargo, now in the Asian Civilisations Museum in Singapore, consisted of about 70000 artefacts, mostly ceramics, including 55000 largely intact Changsha bowls, in addition to the largest single group of T'ang silverware and gold, as well as spices and other foodstuffs. The destination of this staggering load may have been the Caliphate where the demand for the same chinese pottery and its surviving sherds are well-documented. The volume provides an overview of the types of objects which were found onboard, the characteristics of the ship, its possible route, and the conditions which led to its disaster, most likely in the mid- $9^{\text {th }}$ century. Although the volume may not be up to scholarly scrutiny, it introduces important themes and throws light on their connective potentials which have not yet been sufficiently investigated from the perspective of mediaeval Iranian studies.

\section{AUTHORS}

\section{IVÁN SZÁNTÓ}

Eötvös Loránd University, Budapest \& Austrian Academy of Sciences, Vienne 